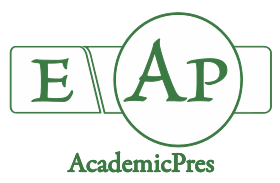

Zandifar Ket al. (2020)

Notulae Botanicae Horti Agrobotanici Cluj-Napoca 48(2):588-603

DOI: $10.15835 /$ nbha48211845

Research Article

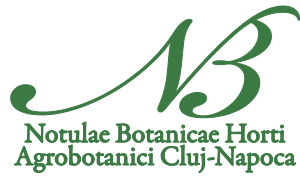

\title{
Phytochemical and morphological diversity analysis of Ziziphus nummularia (Burm.f.) Wight \& Arn. populations in South of Iran
}

\author{
Kourosh ZANDIFAR ${ }^{1}$, Hassanali Naghid BADI ${ }^{2}$, \\ Ali MEHRAFARIN ${ }^{2 *}$, Majid Ghorbani NOHOOJI ${ }^{2}$ \\ ${ }^{1}$ Department of Horticultural Science and Agronomy, Science and Research Branch, Islamic Azad University, Tehran, \\ Iran;K.Zandifar88@gmail.com \\ ${ }^{2}$ Medicinal Plants Research Center, Institute of Medicinal Plants, ACECR, Karaj, \\ Iran;Mehrafarin@imp.ac.ir(*correspondingauthor);Naghdibadi@yahoo.com;M.Gh.Nahooji@gmail.com
}

\begin{abstract}
Ziziphus nummularia is a multipurpose and tropical tree with medicinal, nutritional, industrial, and economic values. This tree, which belongs to the Rhamnaceae family, is originated from the South of Asia and North of Africa. This research was carried out to investigate the phytochemical and morphological diversity of 20 wild populations collected from different Southern regions of Iran. Statistical significant difference ranges between population were found in respect to saponin of the leaf $(2.2-5.4 \mathrm{mg} / \mathrm{g})$ and fruit $(1.2-3.2 \mathrm{mg} / \mathrm{g})$, phenol of the leaf $(0.7-2.9 \mathrm{mg} / \mathrm{g})$ and fruit $(0.03-0.4 \mathrm{mg} / \mathrm{g})$, tannin of the leaf $(0.8-3.5 \mathrm{mg} / \mathrm{g})$ and fruit $(1.5-1.7 \mathrm{mg} / \mathrm{g})$, and flavonoid of the leaf $(3.3-4.3 \mathrm{mg} / \mathrm{g})$ and fruit $(1.5-2.4 \mathrm{mg} / \mathrm{g})$. A factor analysis based on principal component analysis (PCA) revealed that the first three components (PC1-PC3) explain $79.04 \%$ of total variations. The first component (PC1) is explained by the most important traits of the PCA coefficient such as the leaf saponin, width of the end leaf, fruit saponin, length of the end leaf, leaf length and width, and leaf phenol with $42 \%$ of the total variation. Hierarchical cluster analysis divided the populations into four main groups with high diversity. In general, the Izeh Tarakab population had the highest content of leaf and fruit saponin. The content of leaf and fruit saponin as the major secondary metabolite could be a good determinant for detecting diversity in the wild population of $Z$. nummularia.
\end{abstract}

Keywords: flavonoid; phenol; principal component analysis (PCA); saponin; tannin

\section{Introduction}

The genus Ziziphus Mill., which belongs to the Rhamnaceae family, includes a large number of species all around the world. Of these species, five distinct species have been introduced and one hybrid species in the Flora Iranica (Iran plateau region) while four of them have been found in Iran (Rechinger, 1977). $Z$. nummularia (Burm.f.) Wight \& Arn. is one of the Iranian species of the genus and is a tropical tree originated from South Asia and North Africa. This tree is also widely distributed in the south of Iran (Dinarvand and Zarinkamar, 2006). The plant extends from Iran to India and grows in dry and semi-arid regions of sandy and 
rocky soils. The identification key of this species is introduced as follows, deciduous shrub, 1-3 $\mathrm{m}$ high, branches numerous, hardly curved and pubescent with two thorns one straight and the other curved. Leaves alternate, ovate roundish, $5-15$ or rarely $30 \mathrm{~mm}$ long, $5-20 \mathrm{~mm}$ wide, pubescent in both surfaces especially on lower surfaces. Inflorescence pubescent racyme, calyx $3 \mathrm{~mm}$ long, corolla yellow, $3 \mathrm{~mm}$ long, stamens 5 , style bifid, drupe spherical, red or dark brown (Dinarvand and Zarinkamar, 2006). Z. nummularia fruits are very nutritious and are usually eaten freshly. The fruits contain 81 to $97 \%$ of the pulp, $12-23 \%$ TSS, $0.13-1.42 \%$ acidity, $3.1-14.5 \%$ total sugars, $1.4-9.7 \%$ sodium, $5.6 \%$ sucrose, $1.5 \%$ glucose, $2.1 \%$ fructose, and $1.0 \%$ starch. This fruit, as a rich source of vitamin C (Akhtar et al., 2017), is used as laxative and astringent. Moreover, its leaves are used in scabies, boils, and as an expectorant. Given its regrowth ability and its ability to function due to its root system, it is able to maintain its vitality against extreme events such as cold and dry (Mahishwar and Bhandari, 1963). The most suitable temperature for $Z$. nummularia growth is from 25 to $35^{\circ} \mathrm{C}$, exceeding which its formation will reduce (Pandey and Sing, 2010) although the species is evergreen, some of its leaves fall in the hot season (Mahishwar and Bhandari, 1963). Several factors, such as soil and climatic conditions, affect the content of biochemical compounds of plants.

The genotype of the population was revealed as an important factor in the phytochemicals content of the plant tree (Seta et al., 2019). Studying the genetic diversity of any plant species provides important information for breeding programs as natural populations are a useful source of diversity (Awasthi et al., 2009). The plants were selected based on morphological traits of their phenotypic appearances. The phenotype of each plant is composed of genetic and environmental factors. Thus, some of the apparent characters can be used as a marker for the identification, differentiation, and classification of species and visible differences such as flower colour and flower shape can be utilized as morphological features in the identification of different species (Paterson et al., 1991). Furthermore, due to the presence of mutagenic agents and high risk of cancers, it is suggested using antioxidant compounds of the medicinal plant as an appropriate alternative or preservatives. These compounds can also be utilized as the available and rich source of antioxidant constituents in food industries and pharmacy. Furthermore, it has been found that the genetic variation of the cultivars plays an important role in the antioxidant capacity and chemical properties of all populations of jujuba ( $Z$. jujuba) (Gao etal., 2011).

The reasons for conducting the present study are as follows: The importance of $Z$. nummularia species, vast distribution and variation of species, the necessity of preserving of population, lack of a study on diversity evaluation in Iran, and introducing appropriate varieties for the supply of sustainable plant materials according to the needs of industries, and processing the herbal medicines in the country. The main objectives of the study were to identify biodiversity and the most important phytochemical traits of populations, determine the extent of population distribution and introduce populations of $Z$. nummularia with appropriate pharmaceutical value for sustainable cultivation and development in Iran and West Southern Asia. Moreover, comparing and determining the correlation between morphological and phytochemical traits of $Z$. nummularia, identifying its populations in Iran, and introducing of the superior population in qualitative and quantitative traits for reproduction and presentation to the manufacturing and processing industries are the major goals of this study.

\section{Materials and Methods}

\section{Plant materials and morphological measurement}

Natural habitats of $Z$. nummularia presence was identified after reviewing resources and referring to several areas in southern Iran. Z. nummularia leaves were sampled in late summer 2017 (as the maximum foliation period) from young (new one-year-old) and annual branches. Also, Z. nummularia fruits were harvested during two phenological stages in the fall. $Z$. nummularia fruits were sampled by the systematicrandom method in the early stage of fruiting (from immature green fruits), as well as in the late stage of fruiting 
(from fully ripe fruits). The treatments included 16 populations from different regions and natural habitats of Iran (in the provinces of Khuzestan, Kohgiluyeh-Boyer Ahmad, and Fars) with three replications from the same age trees in each region and 5 observations in every tree.

Herbarium specimens of the studied plants were prepared and the accurate identification of collected plants was carried out using valuable references. The voucher specimens were deposited at the Institute of Medicinal Plants Herbarium (IMPH). Detailed area information of collected plants is presented in Table 1. Plant specimens were collected from the longitude of $49^{\circ} 50^{\prime \prime} 12^{\prime}$ to $51^{\circ} 60^{\prime \prime} 67^{\prime}$, latitude of $30^{\circ} 02^{\prime \prime} 41^{\prime}$ to $31^{\circ}$ 70 " 94', altitude of 181 to $948 \mathrm{~m}$, with average annual temperature of 22 to $35^{\circ} \mathrm{C}$. Also, the leaf mass samples were kept at the refrigerator $\left(4 \pm 2{ }^{\circ} \mathrm{C}\right)$ until laboratory testing and analysis. In diversity studies, phytochemical and morphological traits are of particular importance for determining similarities and differences between groups or even in close species. In total, 25 traits were measured based on typical plant indicators with 17 morphological and developmental characteristics as well as 8 important phytochemical and pharmacological characteristics. Geographical regions and morphological characteristics for all populations were measured using laboratory equipment such as GPS and altimeter, millimetre ruler, Sartorius precision scale (with an accuracy of $0.001 \mathrm{~g}$ ), and digital calliper (Table 2). In addition, the qualitative characters were coded in binary or multistate characters, clustered, and standardized (mean $=0$ and variance $=1)$.

\section{Phytochemicalmeasurement}

\section{Preparation of extracts for measurements}

The leaves and unripe and ripe fruits of $Z$. nummularia were dried in the shade at room temperature and then were ground to a fine powder. The powdered plant organs were extracted with $80 \%$ methanol using percolator for $48 \mathrm{~h}$ and then the extracts were dried by rotary apparatus. Finally, the extracts were enriched by complete drying at $60^{\circ} \mathrm{C}$. The prepared methanolic extract was kept at $4^{\circ} \mathrm{C}$ until use. To prepare the aqueous extract, distilled water was used as a solvent. The extraction procedure was done at $25^{\circ} \mathrm{C}$ for $24 \mathrm{~h}$. During this time, the beaker containing the materials was placed on the rotator for better extraction. After centrifuging, the supernatant was removed and dried (Pourmorad et al., 2006).

\section{Total flavonoids}

The amount of total flavonols was estimated by the aluminium chloride method (Ranjith, 2009). The extract was smoothed and placed in a $100 \mathrm{ml}$ balloon with $70 \%$ methanol. Then, $2 \mathrm{ml}$ of methanolic extracts of the plant were mixed with $1.5 \mathrm{ml}$ of methanol, $0.1 \mathrm{ml}$ of aluminium chloride (methanol $10 \%$ ), $0.1 \mathrm{ml}$ of potassium acetate $(1 \mathrm{~mol})$, and $2.8 \mathrm{ml}$ of distilled water. The solutions were then placed at room temperature for $30 \mathrm{~min}$. The absorbance of each composition was measured at $415 \mathrm{~nm}$ with a spectrophotometer (UVVisible Model Cary 300). The standard curve was prepared with quercetin methanolic solutions at concentrations from 250 to $1000 \mu \mathrm{g} / \mathrm{ml}$.

\section{Total phenolics}

To prepare the extract, $0.2 \mathrm{~g}$ of dried plant powder was used for soaking in methanol $70 \%$ at a $3: 1$ ratio (3 parts methanol and 1 part of herbal powder) for $24 \mathrm{~h}$. After $1 \mathrm{~h}$, the specimens were smoothed with filter paper and the solution reached $25 \mathrm{ml}$. To prepare the standard curve, $6 \mathrm{ml}$ were poured standard gallic acid solution. Next, $5 \mathrm{ml}$ of Folin-Denis reagent and $10 \mathrm{ml}$ of $35 \%$ sodium carbonate were added and the distilled water was fed to a volume of $50 \mathrm{ml}$. The beakers were placed at room temperature for $45 \mathrm{~min}$ to maximize colour intensity. The solutions were absorbed by a spectrophotometer (UV-Visible Model Cary 300) apparatus at a wavelength of $760 \mathrm{~nm}$ and in the presence of a Blanc $(5 \mathrm{ml}$ Reagent Folin-Denis). Here, $10 \mathrm{ml}$ sodium carbonate $35 \%$ was determined with a volume of $100 \mathrm{ml}$ and its absorption curve was plotted relative to the concentration. To determine the absorbance of the specimens, $1 \mathrm{ml}$ of the extract was mixed with $5 \mathrm{ml}$ of FolinDenis reagent. Afterward, $10 \mathrm{ml}$ of sodium carbonate $35 \%$ in $100 \mathrm{ml}$ bottles was mixed with distilled water in 
a volume of $100 \mathrm{ml}$ for $45 \mathrm{~min}$ at room temperature to maximize colour intensity. The absorbance of the specimen was read at $760 \mathrm{~nm}$ and, in the presence of a Blanc, the unobstructed sap was calculated according to the standard curve based on mg per $100 \mathrm{ml}$ gallic acid) Wettasinghe and Shahid 1999).

Table 1. Information on collection area of $Z$. nuummularia populations

\begin{tabular}{|c|c|c|c|c|c|c|c|c|c|}
\hline $\begin{array}{l}\mathrm{N} \\
\mathrm{o}\end{array}$ & $\begin{array}{l}\text { Populati } \\
\text { on no. }\end{array}$ & Region originated & $\begin{array}{l}\text { Latitude } \\
\qquad(\mathrm{N})\end{array}$ & $\begin{array}{l}\text { Longitude } \\
\text { (E) }\end{array}$ & $\begin{array}{l}\text { Altitu } \\
\text { de (m) }\end{array}$ & $\begin{array}{c}\text { Average } \\
\text { maximum } \\
\text { temperature } \\
\left({ }^{\circ} \mathrm{C}\right)\end{array}$ & $\begin{array}{c}\text { Average } \\
\text { minimum } \\
\text { temperature } \\
\left({ }^{\circ} \mathrm{C}\right)\end{array}$ & $\begin{array}{c}\text { Average } \\
\text { maximum } \\
\text { moisture (\%) }\end{array}$ & $\begin{array}{c}\text { Average } \\
\text { minimum } \\
\text { moisture } \\
(\%)\end{array}$ \\
\hline 1 & KH1 & Khuzestan - Behbahan & $\begin{array}{c}30^{\circ} 59^{\prime \prime} \\
68^{\prime}\end{array}$ & $\begin{array}{c}50^{\circ} 35^{\prime \prime} \\
21^{\prime} \\
\end{array}$ & 328 & 35.2 & 17 & 88 & 34 \\
\hline 2 & $\mathrm{KH} 2$ & $\begin{array}{l}\text { Khouzestan - } \\
\text { Ramhormoz }\end{array}$ & $\begin{array}{c}31^{\circ} 25^{\prime \prime} \\
55^{\prime}\end{array}$ & $\begin{array}{c}49^{\circ} 63^{\prime \prime} \\
36^{\prime}\end{array}$ & 181 & 30.1 & 20.3 & 76 & 35 \\
\hline 3 & $\mathrm{KH} 3$ & Khuzestan - Haftgol & $\begin{array}{c}31^{\circ} 45 \\
49^{\prime}\end{array}$ & $\begin{array}{c}49^{\circ} 56^{\prime \prime} \\
55^{\prime}\end{array}$ & 315 & 34 & 17.2 & 83 & 39 \\
\hline 4 & KH4 & Khuzestan - Baghmalek & $\begin{array}{c}31^{\circ} 52^{\prime \prime} \\
36^{\prime} \\
\end{array}$ & $\begin{array}{c}49^{\circ} 50^{\prime \prime} \\
12^{\prime} \\
\end{array}$ & 630 & 28 & 15 & 79 & 37 \\
\hline 5 & KH5 & $\begin{array}{c}\text { Khuzestan - Ghaleh } \\
\text { tool Baghmalek }\end{array}$ & $\begin{array}{c}31^{\circ} 65^{\prime \prime} \\
68^{\prime}\end{array}$ & $\begin{array}{c}49^{\circ} 92^{\prime \prime} \\
19^{\prime} \\
\end{array}$ & 701 & 29 & 15.3 & 79 & 39 \\
\hline 6 & KH6 & $\begin{array}{c}\text { Khuzestan - Izeh } \\
\text { Turkab } \\
\end{array}$ & $\begin{array}{c}31^{\circ} 69^{\prime \prime} \\
18^{\prime} \\
\end{array}$ & $\begin{array}{c}49^{\circ} 75^{\prime \prime} \\
05^{\prime} \\
\end{array}$ & 786 & 28 & 14 & 71 & 35 \\
\hline 7 & KH7 & $\begin{array}{c}\text { Khuzestan - Izeh } \\
\text { Jaghband }\end{array}$ & $\begin{array}{c}31^{\circ} 70^{\prime \prime} \\
94^{\prime} \\
\end{array}$ & $\begin{array}{c}49^{\circ} 81^{\prime \prime} \\
28^{\prime} \\
\end{array}$ & 791 & 29 & 13.5 & 68 & 33 \\
\hline 8 & KH8 & $\begin{array}{c}\text { Khuzestan - Izeh } \\
\text { Koolfarh } \\
\end{array}$ & $\begin{array}{c}31^{\circ} 52^{\prime \prime} \\
01^{\prime} \\
\end{array}$ & $\begin{array}{c}49^{\circ} 52^{\prime \prime} \\
00^{\prime} \\
\end{array}$ & 790 & 29.3 & 13.4 & 64 & 40 \\
\hline 9 & F9 & Fars-Qaemea & $\begin{array}{c}29^{\circ} 84^{\prime \prime} \\
14^{\prime} \\
\end{array}$ & $\begin{array}{c}51^{\circ} 60^{\prime \prime} \\
67^{\prime} \\
\end{array}$ & 883 & 23 & 11 & 53 & 22 \\
\hline $\begin{array}{l}1 \\
0 \\
\end{array}$ & F10 & $\begin{array}{c}\text { Fars - Khomezar } \\
\text { Noorabad }\end{array}$ & $\begin{array}{c}30^{\circ} 02^{\prime \prime} \\
41^{\prime} \\
\end{array}$ & $\begin{array}{c}51^{\circ} 56^{\prime \prime} \\
10^{\prime} \\
\end{array}$ & 908 & 25.8 & 11.8 & 69 & 27 \\
\hline $\begin{array}{l}1 \\
1 \\
\end{array}$ & F11 & Fars-Fahliyan Norabad & $\begin{array}{c}30^{\circ} 15^{\prime \prime} \\
61^{\prime} \\
\end{array}$ & $\begin{array}{c}51^{\circ} 53^{\prime \prime} \\
12^{\prime} \\
\end{array}$ & 901 & 25 & 10 & 73 & 34 \\
\hline $\begin{array}{l}1 \\
2 \\
\end{array}$ & F12 & Fars-Mosiry Rostam & $\begin{array}{c}30^{\circ} 15^{\prime \prime} \\
56^{\prime}\end{array}$ & $\begin{array}{c}51^{\circ} 53^{\prime \prime} \\
14^{\prime} \\
\end{array}$ & 920 & 22 & 10 & 56 & 27 \\
\hline $\begin{array}{l}1 \\
3\end{array}$ & F13 & $\begin{array}{l}\text { Fars - Tel pir } \\
\text { Babaamidan }\end{array}$ & $\begin{array}{c}30^{\circ} 26^{\prime \prime} \\
83^{\prime}\end{array}$ & $\begin{array}{c}51^{\circ} 49^{\prime \prime} \\
10^{\prime}\end{array}$ & 948 & 23 & 8 & 57 & 29 \\
\hline $\begin{array}{l}1 \\
4\end{array}$ & F14 & $\begin{array}{l}\text { Fars - Dehno } \\
\text { Babaamidan }\end{array}$ & $\begin{array}{c}30^{\circ} 34^{\prime \prime} \\
04^{\prime}\end{array}$ & $\begin{array}{c}51^{\circ} 30^{\prime \prime} \\
98^{\prime}\end{array}$ & 935 & 23 & 10 & 73 & 38 \\
\hline $\begin{array}{l}1 \\
5\end{array}$ & F15 & Fars - Coupon & $\begin{array}{c}30^{\circ} 33^{\prime \prime} \\
12^{\prime}\end{array}$ & $\begin{array}{c}51^{\circ} 27^{\prime \prime} \\
84^{\prime}\end{array}$ & 917 & 29.1 & 15.4 & 65 & 27 \\
\hline $\begin{array}{l}1 \\
6\end{array}$ & K16 & $\begin{array}{c}\text { Kohgiluyeh and } \\
\text { Boyerahmad - Basht }\end{array}$ & $\begin{array}{c}30^{\circ} 32^{\prime \prime} \\
93^{\prime}\end{array}$ & $\begin{array}{c}51^{\circ} 17^{\prime \prime} \\
99^{\prime}\end{array}$ & 781 & 25 & 11 & 64 & 29 \\
\hline $\begin{array}{l}1 \\
7\end{array}$ & K17 & $\begin{array}{l}\text { Kohgiluyeh and } \\
\text { Boyerahmad - } \\
\text { Gachsaran }\end{array}$ & $\begin{array}{c}30^{\circ} 35^{\prime \prime} \\
12^{\prime}\end{array}$ & $\begin{array}{l}50^{\circ} 80^{\prime \prime} \\
68^{\prime}\end{array}$ & 719 & 26.5 & 12.4 & 62 & 20 \\
\hline $\begin{array}{l}1 \\
8\end{array}$ & K18 & $\begin{array}{l}\text { Kohgiluyeh and Boyer } \\
\text { Ahmad-lick }\end{array}$ & $\begin{array}{c}30^{\circ} 90^{\prime \prime} \\
22^{\prime}\end{array}$ & $\begin{array}{c}50^{\circ} 09^{\prime \prime} \\
67^{\prime}\end{array}$ & 673 & 25 & 9.1 & 51 & 24 \\
\hline $\begin{array}{l}1 \\
9\end{array}$ & K19 & $\begin{array}{l}\text { Kohgiluyeh and Boyer } \\
\text { Ahmad-Dehdasht }\end{array}$ & $\begin{array}{c}30^{\circ} 52^{\prime \prime} \\
32^{\prime}\end{array}$ & $\begin{array}{c}50^{\circ} 45^{\prime \prime} \\
21^{\prime}\end{array}$ & 803 & 26 & 8 & 53 & 22 \\
\hline $\begin{array}{l}2 \\
0\end{array}$ & K20 & $\begin{array}{l}\text { Kohgiluyeh and Boyer } \\
\text { Ahmad - haft } \\
\text { cheshmeh Gachsaran }\end{array}$ & $\begin{array}{l}30^{\circ} 04^{\prime \prime} \\
71^{\prime}\end{array}$ & $\begin{array}{c}50^{\circ} 61^{\prime \prime} \\
43^{\prime}\end{array}$ & 735 & 27.5 & 13.8 & 68.75 & 32 \\
\hline
\end{tabular}

\section{Extraction of tannin}

To measure tannin, to $1 \mathrm{ml}$ of methanolic extract, $1 \mathrm{ml}$ of methanol and $20 \mathrm{mg}$ of polyvinylpyrrolidone was added and then vortexed for 10 seconds and then placed in ice for $30 \mathrm{~min}$. The specimens were then centrifuged for $6 \mathrm{~min}$ a day for $10 \mathrm{~min}$. Then, $1.5 \mathrm{ml}$ of the centrifuge solution was poured into a micro-tube, to which $10 \mathrm{mg}$ of polyvinylpyrrolidone was added and re-extracted. After centrifuging, $1 \mathrm{ml}$ of the extract was removed, and the tannin was measured. To prepare a standard curve in 6 balloons, $50 \mathrm{ml}$ of 1,2,3, 4, 5, and 6 $\mathrm{ml}$ of standard gallic acid solution was poured. Next, $5 \mathrm{ml}$ of reagent Folin-Denis and $10 \mathrm{ml}$ of $35 \%$ sodium carbonate were added, and distilled water was fed to a volume of $50 \mathrm{ml}$. The balloons were placed at room 
temperature for $45 \mathrm{~min}$ to maximize colour intensity. Absorption of solutions was determined by a spectrophotometer at $760 \mathrm{~nm}$ and in the presence of a blender ( $5 \mathrm{ml}$ Reagent Folin-Denis and $10 \mathrm{ml}$ of 35\% sodium carbonate in the volume of $100 \mathrm{ml}$ ), and its adsorption curve was plotted relative to the concentration. To determine the absorbance of the specimen, $1 \mathrm{ml}$ of the extract was mixed with $5 \mathrm{ml}$ of Folin-Denis and 10 $\mathrm{ml}$ of $35 \%$ sodium carbonate in a $100 \mathrm{ml}$ bottle with distilled water in a volume of $100 \mathrm{ml}$ and was placed for $45 \mathrm{~min}$ at room temperature to maximize colour intensity. The absorbance of the specimen was read at $760 \mathrm{~nm}$ in the presence of blanc, and then the unknown concentration was calculated according to the standard curve based on mg per $100 \mathrm{ml}$ of gallic acid. According to this method, tannin compounds were deposited with polyvinylpyrrolidone and their value was calculated based on the difference in absorption (Makkar, 2000).

\section{Extraction of saponin}

To extract and identify saponin, the extract from alcoholic extract (infiltration) was used. For this purpose, a vacuum distillation apparatus was utilized to separate the solvent extract. Also, to identify the saponin and its contents, $1 \mathrm{~g}$ of ethanol extract was added to the test tube and added to the distilled water, then the tube was shaken vigorously for $5 \mathrm{~min}$. Finally, the saponin level was measured after settling for $30 \mathrm{~min}$ (Salehi Surmaghi et al., 1992).

\section{Statistical analysis}

The treatments included 20 different wild populations from natural habitats with 3 sampling replications in each region. The statistical analysis of the data is obtained from this experiment in a complete randomized design (CRD) with three replications. An analysis of variance (ANOVA) appropriate to the experimental design was performed using SPSS software (ver. 24). Mean comparison of the traits was made using Duncan Multiple Range Test at $p \leq 0.05$ significance level. A hierarchical cluster analysis (HCA) of the data was performed based on the Euclidean distances of morphological and phytochemical traits, using the Wards method. To determine the most variable characters among the populations, factor analysis (FA) based on principal component analysis (PCA) was performed.

\section{Results and Discussion}

The ANOVA results showed that most of the morphological and phytochemical traits have a significant difference at the 5\% level, except for the sub-stem length at a $1 \%$ level (Table 2). Moreover, a significant difference was observed between the mean values of leaf and fruit characteristics.

Table 2. Analysis of variance for morphological and phytochemical trials in Ziziphus nummularia populations

\begin{tabular}{|c|c|c|c|c|c|c|c|c|c|c|c|}
\hline \multirow[b]{2}{*}{ S.O.V } & \multirow[b]{2}{*}{ df } & \multicolumn{10}{|c|}{ Mean of square (MS) } \\
\hline & & $\begin{array}{c}\text { Leaf } \\
\text { width }\end{array}$ & $\begin{array}{l}\text { Leaf } \\
\text { length }\end{array}$ & $\begin{array}{c}\text { Number } \\
\text { of } \\
\text { thorns }\end{array}$ & Thorns & $\begin{array}{l}\text { Lateral } \\
\text { stem } \\
\text { length }\end{array}$ & $\begin{array}{l}\text { Flower } \\
\text { stem } \\
\text { length }\end{array}$ & $\begin{array}{l}\text { Interme } \\
\text { diate } \\
\text { length }\end{array}$ & $\begin{array}{l}\text { Annual } \\
\text { branches } \\
\text { length }\end{array}$ & $\begin{array}{c}\text { The } \\
\text { length of } \\
\text { the end } \\
\text { leaf }\end{array}$ & $\begin{array}{l}\text { The } \\
\text { width } \\
\text { of the } \\
\text { end leaf }\end{array}$ \\
\hline $\begin{array}{c}\text { Replicat } \\
\text { ion }\end{array}$ & 2 & $5.994^{\circ}$ & $3.556^{*}$ & $8.15^{* *}$ & $5.162^{*}$ & $1.071^{*}$ & $0.059^{\mathrm{ns}}$ & $0.017^{*}$ & $1163.6^{\mathrm{ns}}$ & $0.079^{* *}$ & $0.009^{\mathrm{ns}}$ \\
\hline $\begin{array}{c}\text { Treatme } \\
\text { nt }\end{array}$ & 19 & $14.207^{*}$ & $12.137^{*}$ & $361.354^{*}$ & $8.632^{*}$ & $0.156^{*}$ & $1.79^{\circ}$ & $0.059^{\circ}$ & $1185.7^{* *}$ & $8 / 786^{\circ}$ & $5.074^{*}$ \\
\hline Error & 38 & 0.458 & 0.419 & 18 & 0.256 & 0.025 & 0.02 & 0.928 & 542.687 & 0.046 & 0.087 \\
\hline $\begin{array}{l}\text { C.V. } \\
(\%)\end{array}$ & - & 6.062 & 4.847 & 9.741 & 4.59 & 8.774 & 3.863 & 2.07 & 8.802 & 2.201 & 4.238 \\
\hline \multirow[b]{2}{*}{ S.O.V } & \multirow[b]{2}{*}{ df } & \multicolumn{10}{|c|}{ Mean of square (MS) } \\
\hline & & $\begin{array}{l}\text { Unripe } \\
\text { fruit } \\
\text { length }\end{array}$ & $\begin{array}{l}\text { Unripe } \\
\text { fruit } \\
\text { width }\end{array}$ & $\begin{array}{l}\text { Ripe } \\
\text { fruit } \\
\text { length }\end{array}$ & $\begin{array}{l}\text { Ripe } \\
\text { fruit } \\
\text { width }\end{array}$ & $\begin{array}{l}\text { Weight } \\
\text { of fruit }\end{array}$ & $\begin{array}{l}\text { Weight } \\
\text { of the }\end{array}$ & $\begin{array}{c}\text { Core weight } \\
\text { of the ripe } \\
\text { fruit }\end{array}$ & $\begin{array}{c}\text { Fruit } \\
\text { saponin }\end{array}$ & $\begin{array}{c}\text { Fruit } \\
\text { tannin }\end{array}$ & $\begin{array}{c}\text { Fruit } \\
\text { flavonoi } \\
\text { ds }\end{array}$ \\
\hline
\end{tabular}




\begin{tabular}{|c|c|c|c|c|c|c|c|c|c|c|c|}
\hline & & & & & & $\begin{array}{c}\text { prematu } \\
\text { re }\end{array}$ & $\begin{array}{l}\text { ripe } \\
\text { fruit }\end{array}$ & & & & \\
\hline $\begin{array}{c}\text { Replicat } \\
\text { ion }\end{array}$ & 2 & $0.005^{\mathrm{ns}}$ & $0.004^{\text {ns }}$ & $0.036^{\mathrm{ns}}$ & $0.006^{*}$ & $0.01^{*}$ & $0.087^{\circ}$ & $0.00022^{\mathrm{ns}}$ & $0.141^{* *}$ & $0.0001^{* *}$ & 0.002 \\
\hline $\begin{array}{c}\text { Treatme } \\
\text { nt }\end{array}$ & 19 & $0.935^{\circ}$ & $1.505^{*}$ & $3.335^{\circ}$ & $3.937^{*}$ & $0.079^{*}$ & $0.473^{\circ}$ & $0.022^{*}$ & $0.846^{*}$ & $0.069^{*}$ & $0.212^{*}$ \\
\hline Error & 38 & 0.033 & 0.026 & 0.013 & 0.005 & 0.035 & 0.005 & 0.0011 & 0.1 & 0.00004 & 0.002 \\
\hline $\begin{array}{l}\text { C.V. } \\
(\%)\end{array}$ & - & 2.45 & 2.563 & 0.961 & 0.572 & 4.099 & 4.576 & 8.001 & 18.813 & 0.113 & 2.186 \\
\hline \multirow[b]{2}{*}{ S.O.V } & \multirow[b]{2}{*}{$\mathrm{df}$} & \multicolumn{10}{|c|}{ Mean of square (MS) } \\
\hline & & $\begin{array}{l}\text { Fruit } \\
\text { phenol }\end{array}$ & $\begin{array}{c}\text { Leaf } \\
\text { saponin }\end{array}$ & $\begin{array}{c}\text { Leaf } \\
\text { tannin }\end{array}$ & $\begin{array}{c}\text { Leaf } \\
\text { flavonoi } \\
\text { ds }\end{array}$ & $\begin{array}{l}\text { Leaf } \\
\text { phenol }\end{array}$ & & & & & \\
\hline $\begin{array}{l}\text { Replicat } \\
\text { ion }\end{array}$ & 2 & $0.0002^{*}$ & $0.117^{*}$ & $0.005^{* \prime}$ & $0.0005^{* \prime}$ & $0.0009^{*}$ & & & & & \\
\hline $\begin{array}{c}\text { Treatme } \\
\text { nt }\end{array}$ & 19 & $0.035^{\circ}$ & $2.834^{*}$ & $1.483^{*}$ & $0.285^{\circ}$ & $1.18^{*}$ & & & & & \\
\hline Error & 38 & 0.004 & 0.021 & 0.002 & 0.0003 & 0.008 & & & & & \\
\hline $\begin{array}{l}\text { C.V. } \\
(\%)\end{array}$ & - & 3.643 & 4.441 & 2.733 & 0.435 & 4.229 & & & & & \\
\hline
\end{tabular}

According to Table 3, the highest value of annual branches length was related to the plants collected from the Khuzestan-Haftkel population (KH3) while its lowest value was found in the specimens related to Khuzestan-Behbahan (KH1). Intermediate length ranged from a low length in Kohgiluyeh and BoyerahmadBasht (K16) to a high length in Fars- Coupon (F15). As shown in Table 3, the highest flower stem length was obtained from plants in the Fars-Qaemea (F9) location, while the lowest peduncle length was recorded from the Kohgiluyeh and Boyerahmad-Basht (K16) location. The samples collected from Khuzestan-Haftkel (KH3) showed the highest lateral stem length while the lowest lateral stem length was observed in the plants from Kohgiluyeh and Boyer Ahmad-Dehdasht (K19). The maximum and minimum thorn lengths were reported from Khuzestan-Ghale Tol Baghmalek (KH5) and Fars-Dehno Baba Meydan (F14; $7.188 \mathrm{~mm}$ ), respectively. The number of thorns ranged from a low value (33.3) in the population of Kohgiluyeh and Boyer Ahmad-Lick (K18) to a high value (64) in the population of Kohgiluyeh and Boyer Ahmad-Dehdasht (K19). The highest lengths of leaf, the end leaf, unripe fruit and ripe fruit were respectively observed in the samples collected from population of Khuzestan-Baghmalek (KH4), Khuzestan-Ramhormoz (KH2), Fars-Coupen (F15), and Khuzestan-Baghmalek (KH4). On the other hand, their lowest lengths were respectively obtained from populations of Kohgiluyeh and Boyer-Ahmad-Basht (K16), Khuzestan-Izeh Kul-e Farah (KH8), Fars-Fahliyan Nourabad (F11), and Fars-Qaemea (F9). In addition, the highest widths of leaf, the end leaf, unripe fruit, and ripe fruit were respectively detected in the samples collected from populations of Khuzestan-Baghmalek (KH4), Khuzestan-Izeh Tarakab (KH6), Khuzestan-Ramhormoz (KH2), and Khuzestan-Ghale Tol Baghmalek (KH5); meanwhile, their lowest widths were respectively observed from populations of Kohgiluyeh and Boyer Ahmad-Dehdasht (K19), Khuzestan-Behbahan (KH1), Fars-Tel Pir Babamaidan (F13), and FarsKopen (F15). The highest value of the weight of premature fruit $(1.07 \mathrm{~g})$, the weight of the ripe fruit $(2.33 \mathrm{~g})$, and core weight of the ripe fruit $(0.54 \mathrm{~g})$ were related to the population of Fars-Fahliyan Nourabad (F11), Khuzestan-Baghmalek (KH4), and Kohgiluyeh and Boyer Ahmad-Haft Cheshmeh Goshsaran, respectively; meanwhile, the lowest values of these traits were observed in a population of Kohgiluyeh and Boyer-AhmadGachsaran (K17), Fars-Kopen (F15), and Fars-Khoome Zar Nourabad (F10), respectively.

Mean comparison results showed that the highest and lowest values of leaf phenol were related to Kohgiluyeh and Boyer Ahmad-Haft Cheshmeh Goshsaran (K20), and Fars-Dehno Baba Meydan (F14), respectively. The highest value of phenol leaf was $\mathrm{K} 20$, which was not significantly different from KH3, KH4, $\mathrm{KH} 5, \mathrm{~K} 18$, and K19 populations. In this study, the highest amount of leaf flavonoids was found in the population of Fars-Tel Pir Baba Meydan (F13), which had a significant difference with Khuzestan-Baghmalek (KH4), and Fars-Khoome Zar Nourabad (F10) populations as the lowest values of populations. The maximum 
and minimum content of leaf tannin were obtained from Khuzestan-Baghmalek (KH4) and Fars-Dehno Baba Meydan (F14), respectively. The highest leaf tannin content was recorded in KH4, which had a significant difference with all populations. The highest amount of leaf saponin was found in the Khuzestan-Izeh Tarakab (KH6) population while its lowest amount was determined in the Fars-Kopen (F15) population (Table 4). The highest amount of fruit phenol, flavonoids, and tannins was observed in the $\mathrm{KH} 2$ population while the highest amount of fruit saponin was obtained in the KH6. The lowest value of fruit phenol, flavonoids, tannins, and saponin was obtained in the K18, KH6, K20, and F12 population, respectively (Table 4).

However, plants from Khuzestan-Ramhormoz (KH2) location showed the highest length of the end leaf, unripe fruit width, fruit phenol, fruit flavonoid, and fruit tannin compared with other populations. Furthermore, the population of Khuzestan-Baghmalek (KH4) had the highest values in characteristics of leaf length, leaf width, ripe fruit length, weight of the ripe fruit, and leaf tannin $(3.5 \mathrm{mg} / \mathrm{g}$ ) (Table 3 and 4). Finally, the amount of leaf and fruit saponin as the most important bioactive ingredient was highest in Khuzestan-Izeh Tarakab (KH6) population (Table 4).

Table 3. Comparison between the means of morphological traits in the studied of $Z$. nummularia populations

\begin{tabular}{|c|c|c|c|c|c|c|c|c|c|c|c|}
\hline $\begin{array}{l}\text { Population } \\
\text { no. }\end{array}$ & $\begin{array}{c}\text { Annual } \\
\text { branches } \\
\text { length } \\
(\mathrm{mm})\end{array}$ & $\begin{array}{l}\text { Intermedi } \\
\text { ate length } \\
(\mathrm{mm})\end{array}$ & $\begin{array}{c}\text { Flower stem } \\
\text { length } \\
(\mathrm{mm})\end{array}$ & $\begin{array}{c}\text { Lateral } \\
\text { stem } \\
\text { length } \\
(\mathrm{mm})\end{array}$ & $\begin{array}{l}\text { Thorns } \\
\text { length } \\
(\mathrm{mm})\end{array}$ & $\begin{array}{l}\text { Number } \\
\text { of thorns }\end{array}$ & \multicolumn{2}{|c|}{$\begin{array}{l}\text { Leaf length } \\
(\mathrm{mm})\end{array}$} & \multicolumn{2}{|c|}{$\begin{array}{l}\text { Leaf width } \\
(\mathrm{mm})\end{array}$} & $\begin{array}{l}\text { Length of } \\
\text { the end } \\
\text { leaf }(\mathrm{mm})\end{array}$ \\
\hline KH1 & $220.33 c$ & $14.34 \mathrm{f}$ & $3.35 \mathrm{~h}$ & $1.68 \mathrm{de}$ & $12.205 \mathrm{bc}$ & $35.00 \mathrm{ef}$ & \multicolumn{2}{|c|}{$9.95 \mathrm{i}$} & \multicolumn{2}{|c|}{$7.815 \mathrm{j}$} & $7.34 \mathrm{~m}$ \\
\hline $\mathrm{KH} 2$ & $277 \mathrm{~b}$ & $18.46 \mathrm{~b}$ & $4.35 \mathrm{~cd}$ & $1.82 \mathrm{cde}$ & $10.81 \mathrm{fgh}$ & $35.67 \mathrm{ef}$ & \multicolumn{2}{|c|}{$14.53 \mathrm{bcd}$} & \multicolumn{2}{|c|}{12.67 bcde } & $12.73 \mathrm{a}$ \\
\hline $\mathrm{KH} 3$ & $321.67 \mathrm{a}$ & $16.51 \mathrm{~d}$ & $3.67 \mathrm{~g}$ & $2.26 \mathrm{a}$ & $12.07 \mathrm{bcd}$ & $43 c$ & \multicolumn{2}{|c|}{$12.06 \mathrm{gh}$} & \multicolumn{2}{|c|}{$10.19 \mathrm{hi}$} & $10.56 \mathrm{ed}$ \\
\hline KH4 & $242.67 \mathrm{bc}$ & $12.64 \mathrm{~h}$ & $3.15 \mathrm{hij}$ & $1.74 \mathrm{de}$ & 10.37 igh & $59 a$ & \multicolumn{2}{|c|}{$16.44 \mathrm{a}$} & \multicolumn{2}{|c|}{$14.91 \mathrm{a}$} & $10.01 \mathrm{f}$ \\
\hline KH5 & $271.67 \mathrm{~b}$ & $13.69 \mathrm{~g}$ & $3.97 \mathrm{ef}$ & $1.79 \mathrm{ed}$ & $14.16 \mathrm{a}$ & $54 a$ & \multicolumn{2}{|c|}{$15.35 \mathrm{abc}$} & \multicolumn{2}{|c|}{$9.25 \mathrm{i}$} & $10.83 \mathrm{~cd}$ \\
\hline KH6 & $271.67 \mathrm{~b}$ & $17.44 \mathrm{c}$ & $4.09 \mathrm{ef}$ & $1.82 \mathrm{cde}$ & 11.15 defgh & $33.67 \mathrm{ef}$ & \multicolumn{2}{|c|}{$15.35 \mathrm{abc}$} & \multicolumn{2}{|c|}{$13.52 \mathrm{~b}$} & $11.87 \mathrm{~b}$ \\
\hline $\mathrm{KH} 7$ & $266.67 \mathrm{~b}$ & $16.67 \mathrm{de}$ & $4.14 \mathrm{ed}$ & $1.78 \mathrm{ed}$ & $12.65 \mathrm{~b}$ & $53.33 \mathrm{~b}$ & \multicolumn{2}{|c|}{14.43 bcde } & \multicolumn{2}{|c|}{$12.67 \mathrm{bcde}$} & $9.51 \mathrm{~g}$ \\
\hline KH8 & $270.67 \mathrm{~b}$ & $15.63 \mathrm{e}$ & $4.14 \mathrm{ed}$ & $1.72 \mathrm{de}$ & $10.26 \mathrm{ih}$ & $50.67 \mathrm{~b}$ & \multicolumn{2}{|c|}{14.42 bcde } & \multicolumn{2}{|c|}{12.40 bcde } & $6.95 n$ \\
\hline F9 & $269.33 \mathrm{~b}$ & $13.57 \mathrm{~g}$ & $5.64 \mathrm{a}$ & $2.15 \mathrm{abc}$ & $11.04 \mathrm{efgh}$ & $44.33 \mathrm{c}$ & \multicolumn{2}{|c|}{$11.66 \mathrm{~h}$} & \multicolumn{2}{|c|}{$9.35 \mathrm{i}$} & $11.12 \mathrm{c}$ \\
\hline F10 & $270.33 \mathrm{~b}$ & $14.63 \mathrm{f}$ & $3.26 \mathrm{hi}$ & $1.58 \mathrm{e}$ & $11.72 \mathrm{cdef}$ & $27.33 \mathrm{~g}$ & \multicolumn{2}{|c|}{$13.54 \mathrm{def}$} & \multicolumn{2}{|c|}{$11.10 \mathrm{fgh}$} & $10.68 \mathrm{~d}$ \\
\hline F11 & $256 \mathrm{bc}$ & $13.43 \mathrm{~g}$ & $4.43 \mathrm{c}$ & $2.19 \mathrm{ab}$ & $11.35 \mathrm{cdef}$ & $43.33 \mathrm{c}$ & \multicolumn{2}{|c|}{$13.13 \mathrm{gf}$} & \multicolumn{2}{|c|}{$10.89 \mathrm{gh}$} & $9.09 \mathrm{~h}$ \\
\hline F12 & $266 \mathrm{~b}$ & $14.76 \mathrm{f}$ & $4.45 c$ & $1.86 \mathrm{cde}$ & 11.94 bcde & $33.33 \mathrm{gf}$ & \multicolumn{2}{|c|}{$15.68 \mathrm{ab}$} & \multicolumn{2}{|c|}{$13.37 \mathrm{bc}$} & $12.45 \mathrm{a}$ \\
\hline F13 & $277.67 \mathrm{~b}$ & $10.6 \mathrm{i}$ & $3.12 \mathrm{hij}$ & $1.85 \mathrm{cde}$ & $9.76 \mathrm{i}$ & $37.33 \mathrm{de}$ & 14. & bcd & 12.83 & & $8.57 \mathrm{ji}$ \\
\hline F14 & $255 \mathrm{bc}$ & $13.52 \mathrm{~g}$ & $3.89 \mathrm{gf}$ & $1.74 \mathrm{de}$ & $7.18 \mathrm{k}$ & $41.67 \mathrm{~cd}$ & 12 & $2 \mathrm{gh}$ & 9.95 & & $8.32 \mathrm{jk}$ \\
\hline F15 & $275.33 b$ & $19.56 \mathrm{a}$ & $3.82 \mathrm{~g}$ & $1.78 \mathrm{de}$ & $8.29 \mathrm{j}$ & $31.33 \mathrm{gf}$ & 14. & $6 \mathrm{cde}$ & 12.661 & & $8.11 \mathrm{lk}$ \\
\hline K16 & $255 \mathrm{bc}$ & $12.35 \mathrm{~h}$ & $2.59 \mathrm{k}$ & $1.70 \mathrm{de}$ & $10.28 \mathrm{ih}$ & $52 \mathrm{~b}$ & & & 16.8 & & $8.55 \mathrm{ji}$ \\
\hline K17 & $260.67 \mathrm{bc}$ & $14.73 \mathrm{f}$ & $3.89 \mathrm{~g}$ & $1.93 \mathrm{bcd}$ & $13.69 \mathrm{a}$ & $61.33 \mathrm{a}$ & 13. & edf & 11.53 & & $8.96 \mathrm{hi}$ \\
\hline K18 & $264 b c$ & $13.62 \mathrm{~g}$ & $3.69 \mathrm{~g}$ & $1.63 \mathrm{de}$ & $11.47 \mathrm{cdef}$ & 33.33 ef & 14. & bcd & 11.71 & & $10.27 \mathrm{ef}$ \\
\hline K19 & $234.67 \mathrm{bc}$ & $14.76 \mathrm{f}$ & $3.07 \mathrm{ij}$ & $1.16 \mathrm{f}$ & $11.22 \mathrm{defg}$ & $64 a$ & 14. & $\mathrm{cde}$ & 7.45 & & 7.861 \\
\hline $\mathrm{K} 20$ & $266.67 \mathrm{~b}$ & $13.36 \mathrm{~g}$ & $4.86 \mathrm{~b}$ & $1.93 \mathrm{bcd}$ & $8.71 \mathrm{j}$ & $34 \mathrm{ef}$ & 14. & $\mathrm{cde}$ & 12.19 & & $11.77 \mathrm{~b}$ \\
\hline $\begin{array}{c}\text { Population } \\
\text { no. }\end{array}$ & $\begin{array}{l}\text { Width of } \\
\text { the end } \\
\text { leaf }(\mathrm{mm})\end{array}$ & $\begin{array}{l}\text { Unripe } \\
\text { fruit } \\
\text { length } \\
(\mathrm{mm})\end{array}$ & $\begin{array}{l}\text { Unripe fruit } \\
\text { width }(\mathrm{mm})\end{array}$ & $\begin{array}{l}\text { Ripe fruit } \\
\text { length } \\
(\mathrm{mm})\end{array}$ & $\begin{array}{c}\text { Ripe fruit } \\
\text { width }(\mathrm{mm})\end{array}$ & $\begin{array}{r}\text { Weigh } \\
\text { prematur } \\
(\mathrm{g})\end{array}$ & $\begin{array}{l}\text { of } \\
\text { fruit }\end{array}$ & $\begin{array}{l}\text { Weiq } \\
\text { ripe }\end{array}$ & $\begin{array}{l}t \text { of the } \\
\text { uit }(\mathrm{g})\end{array}$ & & $\begin{array}{l}\text { re weight of } \\
\text { ripe fruit } \\
\text { (g) }\end{array}$ \\
\hline KH1 & $5.33 \mathrm{i}$ & $6.96 \mathrm{i}$ & $5.45 \mathrm{kj}$ & $13.37 \mathrm{~b}$ & $13.49 \mathrm{~d}$ & 0.75 & & & $0 \mathrm{~cd}$ & & $0.46 \mathrm{c}$ \\
\hline $\mathrm{KH} 2$ & $8.83 \mathrm{ab}$ & $8.07 \mathrm{abc}$ & $8.29 \mathrm{a}$ & $12.14 \mathrm{f}$ & $12.83 \mathrm{f}$ & 0.88 & & & $6 \mathrm{~b}$ & & $0.53 \mathrm{a}$ \\
\hline $\mathrm{KH} 3$ & $7.67 \mathrm{c}$ & $7.07 \mathrm{i}$ & $6.02 \mathrm{gh}$ & $13.40 \mathrm{~b}$ & $14.55 \mathrm{~b}$ & 0.63 & & & $8 \mathrm{~cd}$ & & $0.48 \mathrm{ac}$ \\
\hline KH4 & $7.06 \mathrm{de}$ & $7.16 \mathrm{hi}$ & $5.88 \mathrm{hi}$ & $13.87 \mathrm{a}$ & $13.92 \mathrm{c}$ & 0.87 & & & $3 a$ & & $0.45 \mathrm{ce}$ \\
\hline KH5 & $5.61 \mathrm{hi}$ & $7.54 \mathrm{efg}$ & $6.24 \mathrm{fg}$ & $12.33 \mathrm{ef}$ & $14.67 \mathrm{a}$ & 0.83 & & & $9 \mathrm{~cd}$ & & $0.39 \mathrm{e}$ \\
\hline KH6 & $9.14 \mathrm{a}$ & $7.98 \mathrm{cde}$ & $6.85 c$ & $13.06 \mathrm{c}$ & $13.9 \mathrm{c}$ & 0.69 & & & $3 \mathrm{~cd}$ & & $0.44 \mathrm{ce}$ \\
\hline KH7 & $7.97 \mathrm{c}$ & $7.26 \mathrm{ghi}$ & $6.27 \mathrm{fg}$ & $12.83 \mathrm{~d}$ & $13.32 \mathrm{e}$ & 0.83 & & & $2 \mathrm{cb}$ & & 0.44 ce \\
\hline KH8 & $5.66 \mathrm{hi}$ & $7.01 \mathrm{i}$ & $6.49 \mathrm{def}$ & $12.75 \mathrm{~d}$ & $12.87 \mathrm{f}$ & 0.86 & & & $1 \mathrm{~cd}$ & & $0.42 \mathrm{e}$ \\
\hline F9 & $7.57 \mathrm{~cd}$ & $7.46 \mathrm{fgh}$ & $5.97 \mathrm{hi}$ & $10.55 \mathrm{j}$ & $11.33 \mathrm{k}$ & 0.43 & & & $9 \mathrm{f}$ & & $0.37 \mathrm{f}$ \\
\hline F10 & $7.67 \mathrm{c}$ & $6.54 \mathrm{j}$ & $5.86 \mathrm{hi}$ & $11.25 \mathrm{~h}$ & $11.71 \mathrm{i}$ & 0.53 & & & $2 \mathrm{gh}$ & & $0.24 \mathrm{~h}$ \\
\hline F11 & $7.56 \mathrm{~cd}$ & $6.21 \mathrm{k}$ & $5.67 \mathrm{ji}$ & $10.68 \mathrm{j}$ & $11.82 \mathrm{i}$ & 1.07 & & & $2 \mathrm{gf}$ & & $0.31 \mathrm{~g}$ \\
\hline F12 & $9.12 \mathrm{a}$ & $7.80 \mathrm{cde}$ & $6.60 \mathrm{ced}$ & $11.28 \mathrm{~h}$ & $12.04 \mathrm{~h}$ & 0.53 & & & $5 \mathrm{gf}$ & & $0.33 \mathrm{~g}$ \\
\hline F13 & $6.41 \mathrm{f}$ & $8.23 \mathrm{ab}$ & $5.28 \mathrm{k}$ & $10.94 \mathrm{i}$ & $12.03 \mathrm{~h}$ & 0.65 & & & $5 \mathrm{gh}$ & & $0.44 \mathrm{ce}$ \\
\hline
\end{tabular}




\begin{tabular}{|c|c|c|c|c|c|c|c|c|}
\hline F14 & $5.89 \mathrm{gh}$ & $7.64 \mathrm{ef}$ & $6.73 \mathrm{~cd}$ & $12.13 \mathrm{f}$ & $12.28 \mathrm{~g}$ & $0.73 \mathrm{ed}$ & $1.06 \mathrm{i}$ & $0.37 \mathrm{f}$ \\
\hline F15 & $6.37 \mathrm{fg}$ & $8.38 \mathrm{a}$ & $7.19 \mathrm{~b}$ & $11.33 \mathrm{~h}$ & $11.12 \mathrm{l}$ & $0.63 \mathrm{~g}$ & $1 \mathrm{i}$ & $0.27 \mathrm{~g}$ \\
\hline $\mathrm{K} 16$ & $5.49 \mathrm{hi}$ & $7.99 \mathrm{bcd}$ & $7.26 \mathrm{~b}$ & $11.53 \mathrm{~g}$ & $11.42 \mathrm{jk}$ & $0.62 \mathrm{~g}$ & $1.25 \mathrm{~h}$ & $0.443 \mathrm{ce}$ \\
\hline $\mathrm{K} 17$ & $5.87 \mathrm{hi}$ & $7.24 \mathrm{ghi}$ & $5.66 \mathrm{ji}$ & $10.70 \mathrm{j}$ & $11.48 \mathrm{j}$ & $0.49 \mathrm{i}$ & $0.98 \mathrm{i}$ & $0.52 \mathrm{a}$ \\
\hline $\mathrm{K} 18$ & $6.83 \mathrm{ef}$ & $7.83 \mathrm{cde}$ & $5.81 \mathrm{hi}$ & $12.38 \mathrm{e}$ & $12.18 \mathrm{~g}$ & $0.73 \mathrm{~d}$ & $1.74 \mathrm{e}$ & $0.45 \mathrm{ce}$ \\
\hline $\mathrm{K} 19$ & $5.36 \mathrm{hi}$ & $7.42 \mathrm{fgh}$ & $6.60 \mathrm{cde}$ & $13.75 \mathrm{a}$ & $14.44 \mathrm{~b}$ & $0.95 \mathrm{~b}$ & $1.85 \mathrm{ed}$ & $0.49 \mathrm{ac}$ \\
\hline $\mathrm{K} 20$ & $8.52 \mathrm{~b}$ & $7.71 \mathrm{def}$ & $6.36 \mathrm{efg}$ & $12.45 \mathrm{e}$ & $12.87 \mathrm{f}$ & $0.83 \mathrm{c}$ & $1.83 \mathrm{ed}$ & $0.54 \mathrm{a}$ \\
\hline
\end{tabular}

KH1 = Behbahan, KH2 = Ramhormoz, KH3= Haftgol, KH4= Baghmalek, KH5= Ghaleh tool, KH6= Izeh Turkab KH7= Izeh Jaghband, KH8= Izeh Koolfarh, F9= Qaemea, F10 = Khomezar Noorabad, F11= Fahliyan Norabad F12= Mosiry Rostam ,F13= Tel pir Babaamidan, F14= Dehno Babaamidan, F15= Coupon, K16= Basht, K17= Gachsaran, K18= lick, K19= Dehdasht, K20=haft cheshmeh Gachsaran

Table 4. Comparison between the averages of phytochemical traits of fruit in the studied z. nummularia populations

\begin{tabular}{|c|c|c|c|c|c|c|c|c|}
\hline Population no. & $\begin{array}{c}\text { Leaf } \\
\text { phenol } \\
(\mathrm{mg} / \mathrm{g})\end{array}$ & $\begin{array}{c}\text { Leaf } \\
\text { flavonoids } \\
(\mathrm{mg} / \mathrm{g})\end{array}$ & $\begin{array}{c}\text { Leaf } \\
\text { tannin } \\
(\mathrm{mg} / \mathrm{g})\end{array}$ & $\begin{array}{c}\text { Leaf } \\
\text { saponin } \\
(\mathrm{mg} / \mathrm{g})\end{array}$ & $\begin{array}{c}\text { Fruit phenol } \\
(\mathrm{mg} / \mathrm{g})\end{array}$ & $\begin{array}{c}\text { Fruit } \\
\text { flavonoid } \\
(\mathrm{mg} / \mathrm{g})\end{array}$ & $\begin{array}{c}\text { Fruit } \\
\text { tannin } \\
(\mathrm{mg} / \mathrm{g})\end{array}$ & $\begin{array}{c}\text { Fruit } \\
\text { saponin } \\
(\mathrm{mg} / \mathrm{g})\end{array}$ \\
\hline $\mathrm{KH} 1$ & $1.34 \mathrm{~g}$ & $4.13 \mathrm{~b}$ & $1.67 \mathrm{fg}$ & $2.38 \mathrm{ij}$ & $0.38 \mathrm{~b}$ & $2.45 \mathrm{a}$ & $1.68 \mathrm{~b}$ & $1.36 \mathrm{f}$ \\
\hline $\mathrm{KH} 2$ & $2.44 \mathrm{c}$ & $4.07 \mathrm{c}$ & $2.63 \mathrm{~cd}$ & $3.53 \mathrm{e}$ & $0.41 \mathrm{a}$ & $2.45 \mathrm{a}$ & $1.73 \mathrm{a}$ & $2.33 \mathrm{bc}$ \\
\hline KH3 & $2.84 \mathrm{ab}$ & $4.01 \mathrm{~d}$ & $2.62 \mathrm{c}$ & $2.5 \mathrm{hij}$ & $0.40 \mathrm{ab}$ & $2.33 \mathrm{bc}$ & $1.62 \mathrm{e}$ & $1.43 \mathrm{ef}$ \\
\hline KH4 & $2.84 \mathrm{ab}$ & $3.41 \mathrm{j}$ & $3.57 \mathrm{a}$ & $2.81 \mathrm{fg}$ & $0.38 \mathrm{bc}$ & $2.11 \mathrm{fg}$ & $1.65 \mathrm{c}$ & $1.73 \mathrm{cdef}$ \\
\hline KH5 & $2.86 \mathrm{ab}$ & $3.94 \mathrm{e}$ & $1.51 \mathrm{~h}$ & $3.3 \mathrm{e}$ & $0.40 \mathrm{ab}$ & $2.23 \mathrm{de}$ & $1.45 \mathrm{k}$ & $2.3 \mathrm{bc}$ \\
\hline KH6 & $2.47 \mathrm{c}$ & $3.87 \mathrm{f}$ & $1.72 \mathrm{f}$ & $5.4 \mathrm{a}$ & $0.34 \mathrm{def}$ & $1.58 \mathrm{j}$ & $1.33 \mathrm{n}$ & $3.23 \mathrm{a}$ \\
\hline KH7 & $2.73 \mathrm{~b}$ & $4.33 \mathrm{a}$ & $1.92 \mathrm{e}$ & $2.93 \mathrm{f}$ & $0.32 \mathrm{ghi}$ & $1.97 \mathrm{~h}$ & $1.59 \mathrm{f}$ & $1.43 \mathrm{ef}$ \\
\hline KH8 & $2.27 \mathrm{ed}$ & $4.34 \mathrm{a}$ & $1.62 \mathrm{~g}$ & $3.33 \mathrm{e}$ & $0.35 \mathrm{de}$ & $2.05 \mathrm{~g}$ & $1.63 \mathrm{~d}$ & $1.5 \mathrm{ef}$ \\
\hline F9 & $2.14 \mathrm{e}$ & $3.76 \mathrm{~g}$ & $1.32 \mathrm{ij}$ & $4.13 \mathrm{~d}$ & $0.30 \mathrm{i}$ & $1.74 \mathrm{i}$ & $1.50 \mathrm{j}$ & $2 \mathrm{bcde}$ \\
\hline F10 & $1.23 \mathrm{~g}$ & $3.39 \mathrm{j}$ & $1.16 \mathrm{k}$ & $4.06 \mathrm{~d}$ & $0.31 \mathrm{hi}$ & $1.73 \mathrm{i}$ & $1.51 \mathrm{i}$ & $2 \mathrm{bcde}$ \\
\hline F11 & $2.39 \mathrm{~cd}$ & $4.01 \mathrm{c}$ & $1.24 \mathrm{jk}$ & $4.4 \mathrm{c}$ & $0.37 \mathrm{efg}$ & $1.69 \mathrm{i}$ & $1.53 \mathrm{~h}$ & $2.23 \mathrm{bcd}$ \\
\hline F12 & $1.77 \mathrm{f}$ & $3.85 \mathrm{f}$ & $1.23 \mathrm{jk}$ & $2.76 \mathrm{fgh}$ & $0.36 \mathrm{efgh}$ & $1.88 \mathrm{~h}$ & $1.54 \mathrm{~g}$ & $1.2 \mathrm{f}$ \\
\hline F13 & $2.14 \mathrm{e}$ & $4.35 \mathrm{a}$ & $1.39 \mathrm{i}$ & $2.73 \mathrm{fgh}$ & $0.33 \mathrm{fgh}$ & $1.86 \mathrm{~h}$ & $1.62 \mathrm{e}$ & $1.66 \mathrm{def}$ \\
\hline F14 & $0.79 \mathrm{~h}$ & $3.50 \mathrm{i}$ & 0.831 & $2.7 \mathrm{fgh}$ & $0.34 \mathrm{def}$ & $1.91 \mathrm{~h}$ & $1.52 \mathrm{f}$ & $2.03 \mathrm{bcde}$ \\
\hline F15 & $1.73 \mathrm{f}$ & $3.73 \mathrm{~g}$ & $1.61 \mathrm{~g}$ & $2.28 \mathrm{j}$ & $0.34 \mathrm{def}$ & $2.12 \mathrm{fg}$ & 1.431 & $2.2 \mathrm{bcd}$ \\
\hline K16 & $1.71 \mathrm{f}$ & $3.65 \mathrm{~h}$ & $1.21 \mathrm{k}$ & $2.38 \mathrm{ij}$ & $0.36 \mathrm{~cd}$ & $2.23 \mathrm{de}$ & $1.34 \mathrm{~m}$ & $1.3 \mathrm{f}$ \\
\hline K17 & $2.12 \mathrm{e}$ & $3.87 \mathrm{f}$ & $1.85 \mathrm{e}$ & $2.36 \mathrm{ij}$ & $0.05 \mathrm{l}$ & $2.16 \mathrm{ef}$ & $1.51 \mathrm{i}$ & $1.53 \mathrm{ef}$ \\
\hline K18 & $2.9 \mathrm{ab}$ & $4.08 \mathrm{c}$ & $2.56 \mathrm{~d}$ & $4.6 \mathrm{c}$ & $0.03 \mathrm{~m}$ & $2.32 \mathrm{bc}$ & $1.26 \mathrm{o}$ & $2.4 \mathrm{~b}$ \\
\hline K19 & $2.84 \mathrm{ab}$ & $3.65 \mathrm{~h}$ & $2.95 \mathrm{~b}$ & $2.58 \mathrm{ghi}$ & $0.15 \mathrm{k}$ & $2.27 \mathrm{~cd}$ & $1.26 \mathrm{p}$ & $1.26 \mathrm{f}$ \\
\hline K20 & $2.96 \mathrm{a}$ & $4.34 \mathrm{a}$ & $1.90 \mathrm{e}$ & $5.1 \mathrm{~b}$ & $0.27 \mathrm{j}$ & $2.40 \mathrm{ab}$ & $1.214 \mathrm{q}$ & $2.53 \mathrm{~b}$ \\
\hline
\end{tabular}

$\mathrm{KH} 1=$ Behbahan, $\mathrm{KH} 2=$ Ramhormoz, KH3 = Haftgol, KH4= Baghmalek, KH5= Ghaleh tool, KH6= Izeh Turkab KH7= Izeh Jaghband, KH8= Izeh Koolfarh, F9= Qaemea, F10= Khomezar Noorabad, F11 = Fahliyan Norabad F12= Mosiry Rostam ,F13= Tel pir Babaamidan, F14= Dehno Babaamidan, F15= Coupon, K16= Basht, K17= Gachsaran, K18= lick, K19= Dehdasht, K20=haft cheshmeh Gachsaran

To identify the biodiversity and different chemotypes of $Z$. nummularia populations, their morphological and phytochemical traits were subjected to principal component analysis (PCA) and cluster analysis (CA). The study indicated five components explaining $91.8 \%$ of the total variance in the PCA, of which the first three components (PC1-PC3) comprised more than $79.04 \%$ of the variations (Table 5). The contribution of the first component (PC1) was $41.05 \%$ of the total variance. In PC1, some characteristics such as leaf saponin, the width of the end leaf, fruit saponin, length of the end leaf, leaf length, leaf width, leaf phenol, the weight of the ripe fruit, and leaf peduncle length, and sub-stem length had the highest variance. Besides, in the second component (PC2) with $20.05 \%$ of the total variance, ripe fruit length and width, leaf tannin, core weigh of the ripe fruit, weight of the ripe fruit, leaf saponin, number of thorns, fruit flavonoids, fruit saponin, leaf phenol, and weight of the premature (unripe) fruit had the highest variance. Moreover, the highest variance for the length and width of the premature (unripe) fruit, and fruit tannin was obtained from PC3 (Table 5). 
Table 5. Eigenvectors of the first three principal component axes from PCA analysis of fruit and leaf variables in studied $Z$. nummolaria populations

\begin{tabular}{|c|c|c|c|}
\hline \multirow{2}{*}{ Character } & \multicolumn{3}{|c|}{ Component } \\
\hline & 1 & 2 & 3 \\
\hline Annual branches & .475 & -.321 & .149 \\
\hline intermediate length & .394 & -.074 & -.319 \\
\hline Flower stem length & .624 & -.198 & .003 \\
\hline Lateral stem length & .336 & -.403 & .535 \\
\hline Thorns & .064 & .292 & .539 \\
\hline Number of thorns & -.295 & .632 & .197 \\
\hline Leaf length & .663 & -.257 & .146 \\
\hline Leaf width & .643 & -.263 & .118 \\
\hline Length of the end leaf & .744 & -.274 & -.038 \\
\hline Width of the end leaf & .797 & -.386 & .058 \\
\hline Unripe fruit length & .179 & -.164 & -.697 \\
\hline Unripe fruit width & .252 & -.053 & -.693 \\
\hline Ripe fruit length & .251 & .790 & -.146 \\
\hline Ripe fruit width & .362 & .749 & .099 \\
\hline Weight of the fruit premature & .252 & .548 & .011 \\
\hline Weight of the ripe fruit & .625 & .664 & .142 \\
\hline Core weight of the ripe fruit & .238 & .677 & -.115 \\
\hline Leaf phenol & .630 & .553 & .108 \\
\hline Leaf flavonoids & .370 & .149 & .262 \\
\hline Leaf tannin & .388 & .731 & -.080 \\
\hline Leaf saponin & .814 & -.653 & -.058 \\
\hline Fruit phenol & .179 & -.142 & .170 \\
\hline Fruit flavonoids & -.008 & .628 & -.308 \\
\hline Fruit tannin & -.015 & -.053 & .544 \\
\hline Fruit saponin & .783 & -.615 & -.310 \\
\hline$\%$ of Variance & 41.053 & 20.054 & 9.666 \\
\hline Cumulative \% & 41.053 & 67.205 & 79.035 \\
\hline
\end{tabular}

However, a highly significant variation was detected in some morphological and phytochemical characters. Six morphological traits including width of the end leaf, length of the end leaf, leaflength, leaf width, weight of the ripe fruit, and leaf peduncle length and three phytochemical traits including content of leaf saponin, fruit saponin, and leaf phenol revealed the highest variation and PCA coefficient according to the results of PCA (Tables 5 and 6). The lowest content of leaf saponin was detected in F15 population, whereas its highest content was recorded in KH6 population. In addition, fruit saponin content varied from F12 to $\mathrm{KH} 6(3.23 \mathrm{mg} / \mathrm{g})$ in the studied populations. The lowest and highest content of leaf phenol was measured in F14 and K20 populations, respectively. In general, total saponin, phenol, and tannin contents of leaf and fruit in PC1 and PC2 were most important for identifying the chemotypes and populations.

The wide range of variation across the $Z$. nummularia populations in the content of saponin and phenol could be exploited for selecting suitable genotypes and also for the improvement and commercial exploitation of this plant. Therefore, the saponin content was the main variable in chemical constituents for the effective detection of original populations of $Z$. nummularia. Based on PC1 and PC2 of these traits, $Z$. nummularia populations were divided into four main groups with similar clustering results.

A cluster analysis of studied populations was performed for grouping populations based on the Euclidean distances of all morphological and phytochemical traits, using the Wards method. In general, hierarchical cluster analysis divided the populations into four main groups with high diversity (Figure 1). The first main group (I) was divided into six populations. The first group consisted of populations from Behbahan 
(KH1), Haftkel (KH3), Baghmalek (KH4), Ghale Tol Baghmalek (KH5), Izeh Jughband (KH7), and Izeh Kul-e Farah (KH8) with similar characteristics. The second main group (II) was divided into four populations comprised of Ramhormoz (KH2), Izeh Tarakab (KH6), Lick (KH18), and Haft Cheshmeh Gachsaran (KH20) population. The third group (III) consisted of nine populations of Qaemea (F9), Khoome Zar Nourabad (F10), Fahliyan Nourabad (F11), Masiri Rostam (F12), Tel Pir Baba Meydan (F13), Dehno Baba Meydan (F14), Kopen (F15), Basht (K16), and Gachsaran (K17). At last, the fourth group (IV) comprised only one population of Dehdasht (K19). Some of the prominent characteristics of these populations are saponin and phenol contents in leaf and fruit and weight of the ripe fruit, which made them distinct among the other populations (Table 6).

Table 6. Morphological and phytochemical characteristics for categorized groups of $Z$. nummolaria populations in Iran

\begin{tabular}{|c|c|c|c|c|}
\hline \multirow{2}{*}{ Character } & \multicolumn{4}{|c|}{ Group cluster (Mean \pm SD) } \\
\hline & I & II & III & IV \\
\hline Population & $\begin{array}{c}\mathrm{KH} 1, \mathrm{KH} 3, \mathrm{KH} 4, \\
\mathrm{KH} 5, \mathrm{KH} 7 \text {, and } \\
\mathrm{KH} 8\end{array}$ & $\begin{array}{l}\mathrm{KH} 2, \mathrm{KH} 6 \text {, } \\
\mathrm{K} 18 \text {, and } \mathrm{K} 20\end{array}$ & $\begin{array}{l}\text { F9, F10, F11, F12, } \\
\text { F13, F14, F15, K16, } \\
\text { and K17 }\end{array}$ & K19 \\
\hline Flower stem length & $3.76 \pm 0.4$ & $3.99 \pm 0.372$ & $3.88 \pm 0.852$ & $3.05 \pm 0.027$ \\
\hline Leaf length & $13.93 \pm 2.425$ & $14.80 \pm 0.440$ & $13.09 \pm 1.874$ & $14.35 \pm 0.12$ \\
\hline Leaf width & $11.20 \pm 2.593$ & $12.64 \pm 0.936$ & $12.06 \pm 2.123$ & $7.46 \pm 0.025$ \\
\hline Length of the end leaf & $9.27 \pm 1.61$ & $11.62 \pm 1.25$ & $9.54 \pm 1.43$ & $7.86 \pm 0.393$ \\
\hline Width of the end leaf & $6.55 \pm 1.159$ & $8.26 \pm 1.254$ & $6.88 \pm 1.112$ & $5.36 \pm 0.132$ \\
\hline Weight of the ripe fruit & $2.09 \pm 0.168$ & $1.93 \pm 0.195$ & $1.27 \pm 0.194$ & $1.85 \pm 0.393$ \\
\hline Leaf phenol & $2.48 \pm 0.6$ & $2.60 \pm 0.255$ & $1.78 \pm 0.475$ & $2.84 \pm 0.382$ \\
\hline Leaf saponin & $2.87 \pm 0.396$ & $4.51 \pm 0.937$ & $3.09 \pm 0.804$ & $2.58 \pm 0.246$ \\
\hline Fruit saponin & $1.68 \pm 0.353$ & $2.65 \pm 0.501$ & $1.79 \pm 0.362$ & $1.26 \pm 0.323$ \\
\hline $\begin{array}{l}\text { Average maximum } \\
\text { temperature }\left({ }^{\circ} \mathrm{C}\right)\end{array}$ & 31.3 & 27.5 & 24.6 & 26 \\
\hline $\begin{array}{l}\text { Average minimum } \\
\text { temperature }\left({ }^{\circ} \mathrm{C}\right)\end{array}$ & 15.7 & 13.85 & 12.2 & 8 \\
\hline $\begin{array}{c}\text { Average maximum moisture } \\
(\%)\end{array}$ & 76.8 & 68.75 & 63 & 53 \\
\hline $\begin{array}{c}\text { Average minimum moisture } \\
(\%)\end{array}$ & 39.13 & 32 & 28 & 22 \\
\hline
\end{tabular}

KH1 = Behbahan, KH2 = Ramhormoz, KH3= Haftgol, KH4= Baghmalek, KH5= Ghaleh tool, KH6= Izeh Turkab KH7= Izeh Jaghband, KH8= Izeh Koolfarh, F9= Qaemea, F10 = Khomezar Noorabad, F11 = Fahliyan Norabad F12= Mosiry Rostam ,F13= Tel pir Babaamidan, F14= Dehno Babaamidan, F15= Coupon, K16= Basht, K17= Gachsaran, K18= lick, K19= Dehdasht, K20=haft cheshmeh Gachsaran 


\section{Distance}

(A)

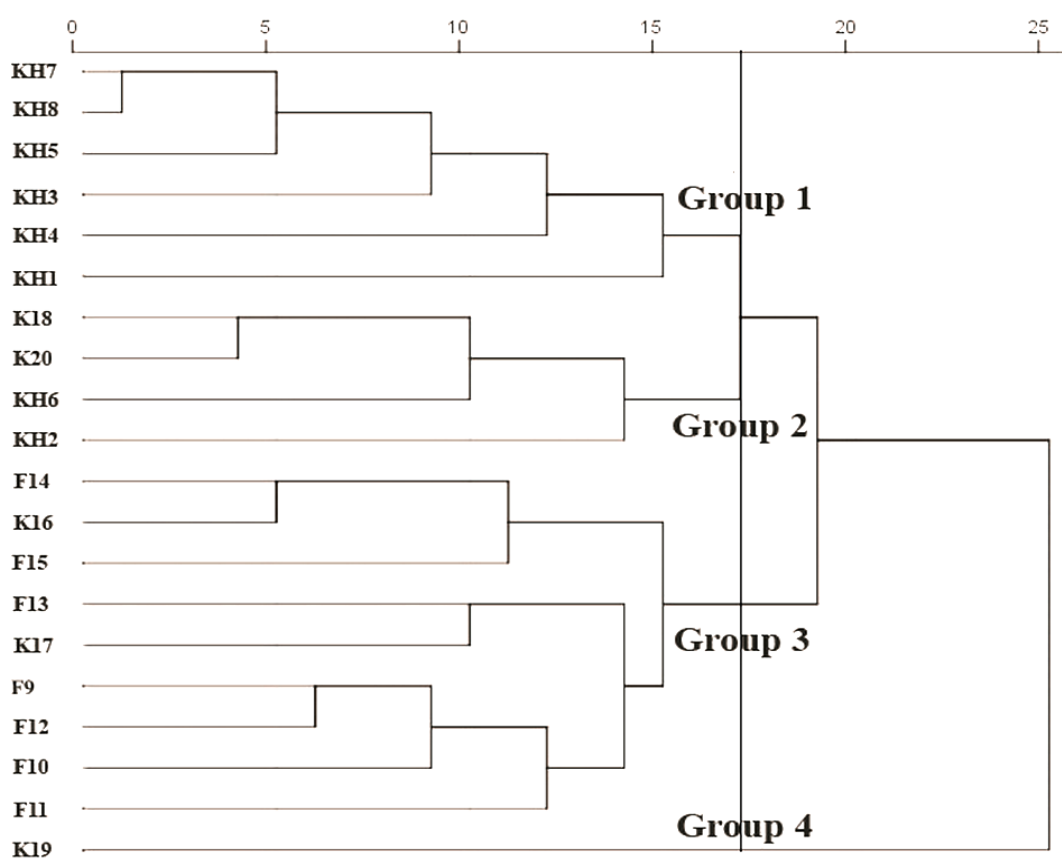

(B)

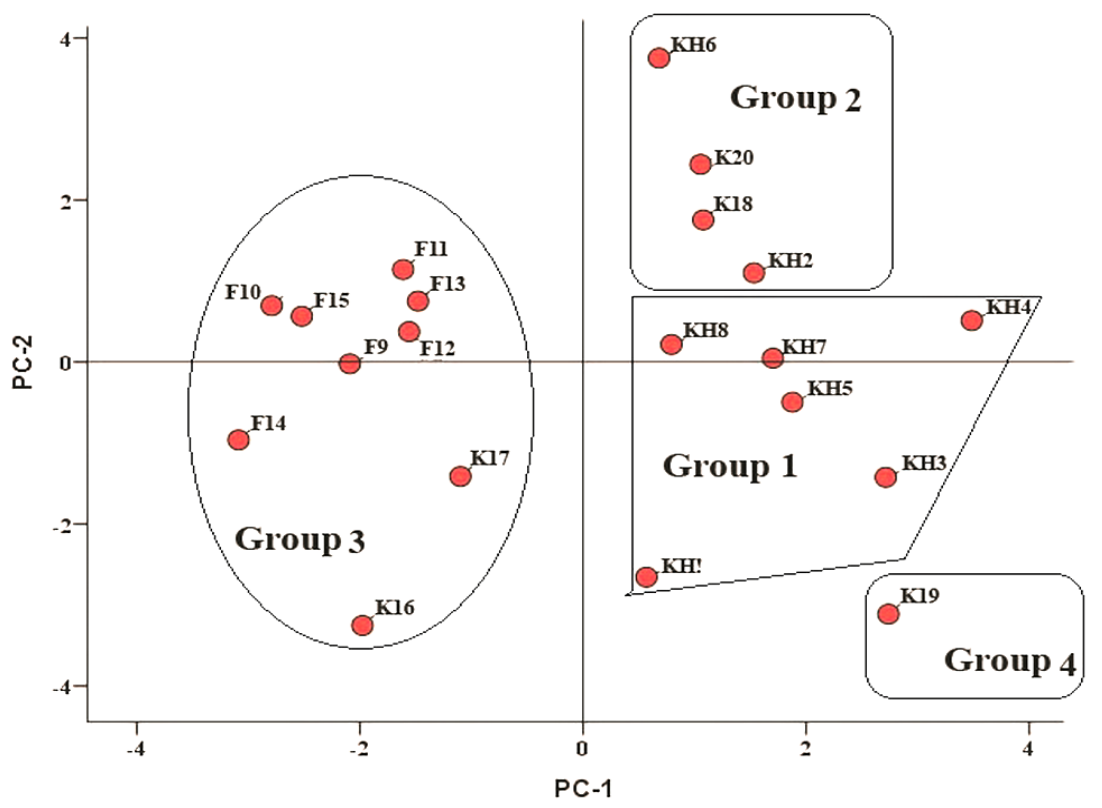

Figure 1. Cluster (A) and PCA (B) analyses of $Z$. nummolaria populations based on the first and second components (PC1 and PC2)

$\mathrm{KH} 1=$ Behbahan, $\mathrm{KH} 2$ = Ramhormoz, KH3 = Haftgol, KH4= Baghmalek, KH5= Ghaleh tool, KH6= Izeh Turkab KH7= Izeh Jaghband, KH8= Izeh Koolfarh, F9= Qaemea, F10= Khomezar Noorabad, F11= Fahliyan Norabad F12= Mosiry Rostam ,F13= Tel pir Babaamidan, F14= Dehno Babaamidan, F15= Coupon, K16= Basht, K17= Gachsaran, K18= lick, K19= Dehdasht, K20=haft cheshmeh Gachsaran 
Phytochemical and morphological traits are affected by the climatic, geographic and soil conditions of the growth site. Therefore, the division of populations into four different clusters could be due to differences in environmental and genetic factors. Thus, this group classification can interpret the results of differences between populations. In different ecosystems, performance and yield of plants were affected by the number of factors such as plant species, climate height of area from sea level, temperature, and relative humidity (Bernath, 2002; Islam et al., 2019). In a recent study, according to the results of environmental factors, the climatic changes significantly affected the qualitative and quantitative yields in populations under study (Rajeswara $e t$ al., 1990). Considering the results of cluster analysis, the most resemblance in the individual's first occupied cluster was due to the saponin content. In comparison, the resemblance between individuals in clusters II and III came from the fruit size and the leaf size in the fourth cluster. The highest saponin content was estimated in KH6 in cluster II. The highest mature fruit weight was measured in KH2 in cluster II and K16 in cluster III. The lowest temperature and relative humidity were measured in the fourth cluster. Therefore, it was deduced that the leaf size was probability affected by the lowest temperature and relative humidity. Furthermore, the temperature and relative humidity seemed very close in clusters II and III, leading to similar fruit weight in these clusters. The highest temperature and relative humidity were measured in cluster I and saponin content. It was concluded that high temperature and relative humidity may lead to high saponin content in individuals.

It was also inferred that high temperature and relative humidity may lead to high saponin content in individuals. Obeed et al. (2008) examined the morphological traits and the fruition of some populations of trees and reported large variations in tree height, leaf length, and branch and fruit traits. They identified these traits as the most reliable traits for the classification of cultivars and populations. In a study on Fars populations of $Z$. nummularia in Iran, a significant difference was obtained between various regions in terms of the morphological traits and the phenological stages (Jahromi and Zandi, 2012). They also concluded that $Z$. nummularia belonging to arid regions are more and longer than wet areas. These results are close to those of the present study. Tatari et al. (2016) reported that Jujube in humid and cold regions has fewer shoot thorns, thinner and smaller thorns, smaller shoots, and taller trees with wider canopies, while in arid and semi-arid regions it has more shoot thorns, thicker and higher thorns, longer shoots, and shorter trees with denser canopies. Climatic conditions have high effects on the morphological traits of Jujube ecotypes and their vegetative characteristics. Isfahan province of Iran is experiencing climate change such as reduced rainfall, drought, and warmer temperatures. An effective factor in justifying the greater diversity within the population is the number of cases such as plant grown-ness, seed germination, number of allele locations, allele position and population genotype, type of crosses, and population size. Saeedi et al. (2016), based on the cluster analysis of different populations of jujube in Iran, divided the studied specimens into eight groups. Here, the lack of compliance in cluster analysis and the placement of ecotypes together could be due to genetic differences.

In another paper on leaf variation of Z. nummularia (Zizyphus christi-spina) in Abolfars, Khuzestan province of Iran, it was reported that except for the leaf thickness trait, the remaining traits in the three habitats have significant differences. The results indicate that the high morphological diversity of $Z$. nummularia leaves in the studied habitats. According to the results, the petiole and thigh lengths are most affected by environmental conditions (Alidadi et al., 2014). Another study showed that altitude above sea level is quite effective in determining the morphological characteristics of $Z$. nummularia. As this species is deciduous, it can grow and extend at altitudes up to 1,200 meters above sea level. In the evaluation of phytochemical traits, the mean comparison results showed that most of the populations had a significant difference in these traits (Arndt et al., 2001).

In a study on the hydro-alcoholic extract of leaf and fruit of $Z$. nummularia, Gupta et al. (2011) observed that leaf flavonoid content in the extract was higher than that of fruit. They reported that the hydro-alcoholic extract of $Z$. nummularia fruit had the highest phenol and its leaf extract had the highest flavonoid content. In this study, the highest amount of tannin of fruit belonged to $\mathrm{KH} 2$, which had a significant difference with all populations. The highest level of saponin in the fruit was also in KH6, in which the population was significantly 
different from other populations. Saponin is one of the several important constituents of $Z$. nummularia leaves and fruits. The high content of saponin has emerged as a desirable factor in the selection of sea buckthorn suitable genotypes. In a study carried out on different $Z$. nummularia masses to investigate the number of phytochemicals present in the tree, it was shown that the amount of minerals in the fruit of $Z$. nummularia depends on the climate, soil elements, harvest time, altitude, and genetics of the mass (Bouis, 1996). The results showed that the highest levels of saponin were in populations KH6 and K20, while the lowest was among populations F15 and K17. In a study by Bagdi and Rathore (2016) on Z. nummularia, it was concluded that saponins are present in the leaf extract, but not in its fruit; these results are inconsistent with those of the present study. In this study, saponin was present in leaf and fruit, but the content of saponin was greater than the content of saponin in the fruit. Moreover, the highest flavonoid content of the whole leaf belonged to the population of F13 and K20, and the low content was seen in F10. This result is in agreement with the results of the research conducted by Gupta et al. (2011) on Z. nummularia. The results showed that leaf and fruits of Z. nummularia have high phenolic content, and populations $\mathrm{K} 20$ and $\mathrm{KH} 2$ are higher in phenol compared to the rest of the populations.

In another work, it was reported that planting of different populations in environmental and geographical conditions increased the environmental effects of vegetative and reproductive traits; moreover, the variety resulted in bigger genetic differences among populations. This variety will pave the way for introducing optimal ecotypes from the perspective of vegetation. Thus, by comparing environmental conditions, it is possible to considered and compare morphological and phytochemical traits (Bahari et al., 2015). Li et al. (2009) evaluated the genetic diversity among 117 jujubes collected from different areas. The results showed high genetic diversity in the samples and, therefore, the high potential for correcting these species. In their study, there was no relationship between geographic regions and genetic distances. Elsewhere, Saeedi et al. (2016) studied the Ziziphus species genetic variation and reported that the cultivars' mass collections of the region were genetically different, probably due to the climatic conditions. In the present research, the most important characteristics of populations of $Z$. nummularia were phytochemical traits, especially saponins in fruits, leaves, and phenols in leaves. Among the populations evaluated, the KH6 population was the highest in the fruit saponin and leaf saponin while K20 was the highest in phenol leaf.

According to the results, the fluctuations in temperature, altitude, and geographic coordinates of the population have created a variety of them. It is suggested prioritizing the importance of the medicinal and nutritional value of these species and their importance for soil stabilization, desertification, crop management and stabilization of its developmental sands. Moreover, it is recommended conducting similar research projects to determine the populations.

\section{Conclusions}

In this study, the important morphological and phytochemical traits of $Z$. nummularia populations in the main regions of Iran were evaluated. There was wide variability in morphological and phytochemical of different $Z$. nummularia populations in the study areas. The results of this research revealed valuable information about the morphological and phytochemical evaluated from wild populations of $Z$. nummularia in Iran. In general, hierarchical cluster analysis and principal component analysis (PCA) divided the wild populations of $Z$. nummularia into four main groups with high diversity. The wide range of variation across the $Z$. nummularia populations in the content of saponin and phenol as the major compounds could be exploited for selecting suitable chemotypes for the improvement and commercial exploitation of this plant. Therefore, the saponin content was the main variable in chemical constituents for the effective detection of original populations of $Z$. nummularia. Generally, Izeh Tarakab population had the highest amount of leaf and 
fruit saponin. The high saponin content emerged as a desirable factor in selecting $Z$. nummularia suitable genotypes.

\section{Authors' Contributions}

The first author carried out the experiment and collected available literature and prepared the first draft of the manuscript with support from the second and third authors. The second author analysed the statistical data and verified the accuracy of the tests. The third author designed the model and the computational framework and he was also responsible for the correspondence. The fourth author edited the manuscript as a plant science consultant.

\section{Conflict of Interests}

The authors declare that there are no conflicts of interest related to this article, and the authors are responsible for the content of the paper.

\section{References}

Akhtar Y, Choudhary R, Sharma KC, Sharma M (2017). Genetic variability and relationship studies of Ber Ziziphus nummularia (Burm. F.) using morphological and molecular markers. Pharmacognosy Journal 9(3):417-424.

Alidadi F, Alia D, Taleshi H, Sefidi K (2014). Investigation on the variation of Zizyphus spina-christi on altitude gradient, case study (area Abolfazar, Khuzestan Province). The first electronic conference on new findings in the environment and agricultural ecosystems.https://www.civilica.com/Paper-AGROCONGRESSO1-AGROCONGRESSO1_214

Arndt S, Clifford S, Popp M (2001). Ziziphus a multipurpose fruit tree for arid regions. In: Breckle SW, Veste M, Wucherer W (Eds). Sustainable land-use in deserts. Springer, Heidelberg, Stuttgart, New York pp 388-399. https://link.springer.com/chapter/10.1007/978-3-642-59560-8_41

Awasthi OP, More TA (2009). Genetic diversity and status of Ziziphus in India. Acta Horticulturae 840:33-40. https://doi.org/10.17660/ActaHortic.2009.840.2

Bagdi P, Rathore V (2016). Phytochemical investigation of extracts of Ziziphus nummularia (Burm. F. Wight \& Arn) leaves and fruits. The Pharmaceutical and Chemical Journal 3(4):220-226. http://tpcj.org/download/vol-3-iss-4-2016/TPCJ201603-04-220-226.pdf

Bahari Z, Shojaeiyan A, Rashidi MS, Mirshekari A, Naira K, Amiriyan M (2015). Investigation of genetic diversity among some Iranian dill (Anethum graveolens L.) landraces, using ISSR markers. Journal of Plant Genetic Research 2:11-22.

Bernath J (2002). Medicinal and aromatic plants. Mezo Publication. Budapest pp 667.

Bouis HEA (1996). Food demand system based on demand for characteristics: If there is curvature in the Slutsky Matrix, what do the curves look like and why? Journal of Development Economics 51(2):239-266. https://doi.org/10.1016/S0304 3878(96)00414-2

Dinarvand M, Zarinkamar F (2006). Anatomy-taxonomy of the genus Ziziphus in Iran. Iranian Journal of Botany 12(1):36-41 http://ijb.areeo.ac.ir/article_102705_be8e42cebc13496c83c221e92a91cd47.pdf

Gao QH, Wu PT, Liu JR, Wu CS, Parry JW, Wang M (2011). Physico-chemical properties and antioxidant capacity of different jujube (Ziziphus jujube Mill) cultivars grown in loess plateau of China. Scientia Horticulturae 130(1): 67-72. https://doi.org/10.1016/j.scienta.2011.06.005

Gupta MS, Jain I, Rajinder K (2011). Phytochemical, nutritional and antioxidant activity evaluation of fruits of Ziziphus nummularia Burm. F.. International Journal of Pharma and Bio Sciences 2:629-638. 
Islam MM, Barman A, Kundu GK (2019). Vulnerability of inland and coastal aquaculture to climate change: Evidence from a developing country. Aquaculture and Fisheries 4(5):183-189.

Jahromi MSM, Zandi P (2012). Investigation on phenology of Ziziphus genus at Fars province. Iranian Journal of Forest and Poplar Research 20(1):122. https://www.sid.ir/fa/journal/ViewPaper.aspx?FID=71913914710

Li JD, Bi HT, Li HT, Li ZS, Fenga JC (2009). Genetic analysis of Ziziphus jujuba 'huizao' using ISSR markers. Acta Horticulturae 840:135-142. https://www.actahort.org/books/840/840_15.htm

Mahishwar JKB (1963). The flora of Delhi. Council for Scientific and Industrial Research New Delhi. pp 102. https://doi.10.17660/ActaHortic.2009.840.15

Makkar HPS (2000). Quantification of tannins in tree foliage. A laboratory manual for the fao/iaea co-ordinated research project on use of nuclear and related technique to develop simple tannin assays for predicting and improving the safety and efficiency of feeding ruminants on tanniniferous tree foliage. FAO/IAEA Working Document. IAEA, Vienna, Austria. http://www-naweb.iaea.org/nafa/aph/public/pubd31022manual-tannin.pdf

Obeed RS, Harhash AL, Abdel-Mawgood AL (2008). Fruit properties and genetic diversity of five ber (Ziziphus mauritiana Lam) cultivars. Pakistan Journal of Biological Science 11:888-893. https://doi.10.3923/pjbs.2008.888.893

Pandey A, Sing R (2010). Exploring the potential of Ziziphus nummularia Wight \& Arn. from drier regions of India. Genet Resource 57:929-936. https://doi.org/10.1007/s10722-010-9566-4

Paterson AH, Tanksley SD, Sorrels ME (1991). DNA markers in plant improvement. Advances in Agronomy 46:39-90. https://doi.org/10.1016/S0065-2113(08)60578-7

Pourmorad F, Hosseinimehr S, Shahabimajd N (2006). Antioxidant activity, phenol and flavonoid contents of some selected Iranian medicinal plants. African Journal of Biotechnology 5:1142-1145. http://www.academicjournals.org/app/webroot/article/article1379770522_Pourmorad\%20et\%20al.pdf

Rajeswara R, Bhaskaruni R, Kakarapsrthi P (1990). Variation in yields and quality of geranium, under varied climatic and fertility conditions. Journal of Essential oil Research 2:73-79. https://doi.org/10.1080/10412905.1990.9697827

Ranjith A (2009). Phytochemical investigation on sea buckthorn (Hipppophae rhamnoides L.) berries. Dissertation in chemistry, National Institute for Interdisciplinary Science and Technology (CSIR). Thiruvananthapuram-19, Kerala, India, pp 222.

Rechinger KH (1977). Flora Iranica. Flora Des Iranischen Hochlandes Und Der Umrahmenden Gebirge. Persien, Afghanistan, Teile Von West-Pakistan, Nord-Iraq, Azerbaidjan, Tur, vol 125- Pp. 4-11-Graz Akademische Druck-und. Verlagsanstalt.

Saeedi K, Shah HR, Tavakoli H, Saadatjou B (2016). Evaluation of some phytochemical, morphological and mineral traits of different populations (Ziziphus jujuba Mill.) (Medicinal plants of jujube). Iranian Journal of Medicinal and Aromatic Plants 32(2):e245-e254. http://dx.doi.org/10.22092/ijmapr.2016.106559

Salehi SMH, Aynehchi Y, Amin GH, Mahmoodi Z (1992). Survey of Iranian plants for saponin alkaloids flavonoids and tanins. IV. DARU Journal of Pharmaceutical Sciences 2(2-3):1-11.

Seta T, Demissew S, Woldu Z (2019). Floristic diversity and composition of the Biteyu forest in the Gurage mountain chain (Ethiopia): implications for forest conservation. Journal of Forestry Research 30(1):319-335.

Tatari M, Ghasemi A, Mousavi A (2016). Genetic diversity in Jujube germplasm (Ziziphus jujube Mill.) based on morphological and pomological traits in Isfahan province, Iran. Crop Breeding Journal 6(2):79-85. http://dx.doi.org/10.22092/cbj.2016.107110

Wettasinghe M, Shahid F (1999). Antioxidant and free radical-scavenging properties of ethanolic extracts of defatted borage (Borago officinalis L.) seeds. Food Chemistry 67:399-414. 
OPEN ACCESS

(c)

The journal offers free, immediate, and unrestricted access to peer-reviewed research and scholarly work. Users are allowed to read, download, copy, distribute, print, search, or link to the full texts of the articles, or use them for any other lawful purpose, without asking prior permission from the publisher or the author.

License - Articles published in Notulae Botanicae Horti Agrobotanici Cluj-Napoca are Open-Access, distributed under the terms and conditions of the Creative Commons Attribution (CC BY 4.0) License. (c) Articles by the authors; UASVM, Cluj-Napoca, Romania. The journal allows the author(s) to hold the copyright/to retain publishing rights without restriction. 